\title{
LEADING SECTORS 15 COUNTRIES-DISTRICTS IN CENTRAL JAVA
}

\author{
${ }^{1}$ Daryono Soebagiyo, Arifin Sri Hascaryo \\ ${ }^{1}$ Faculty of Economics and Business, University of Muhammadiyah Surakarta \\ Campus A Yani Tromolpos 1 Pabelas Kartasura Surakarta 57102 \\ Phone (0271) 717417 \\ Correspondence E-mail: daryono51@ymail.com
}

Recieved: Januari 2016; Accepted: June 2016

\begin{abstract}
Sectors of the economy is vital to the economic growth of a region. A sector can be said to be high productivity levels and if the sector is able to absorb a large workforce and the use of human resources as efficiently as possible. Each area has advantages in certain sectors which could be a contributor to economic growth. This study was conducted to determine and explain the influence of the areas that have a particular advantage to economic growth. Measurements using the Location Quotient leading sectors, whereas the determinant analysis using panel data. This research is expected to know the areas that have the basic sector and determine its impact on economic growth in Central Java. An area is said to have a dominant sector if it has a score of more than 1 and is said not to have if less than 1 . The sample used in this study are 15 city/county for the years from 2007 to 2011 . The results of the analysis using the LQ shows that in 2007-2011 there were about eight areas that excel in the agricultural sector, 9 in the industrial and commercial sector.
\end{abstract}

Keywords: Economics Growth, Leading Sector, Location Quotient JEL Classification: $\mathrm{O} 18$

\section{Introduction}

Economic globalization requires that the Republic of Indonesia is also charged ready to compete with other countries. In order to compete Indonesia must establish beforehand the economy. In improving the readiness of governments in the face of globalization needed a strong and stable economy. National economic development can not be separated from economic development on a regional basis. In essence the regional development is the implementation of national development in certain regions that are tailored to the ability of the regional economy.

Regional economic development is a process by which local governments and communities to manage existing resources and form a pattern of a partnership between local governments and the private sectors to create a new jobs and stimulate the development of economic growth in the region. Each regional economic development effort has the main goal to increase the number and types of employment and competitiveness for local communities. In an effort to achieve these objectives, the local government and the community should jointly take the initiative of local development where existing resources to be able to assess the potential needed to design and build the local economy.

Economic potential in each area need to be explored and used efficiently and effectively to support development and economic growth in the region. Economic development potential leading sectors that provide the greatest contribution to the economic progress of the region is a priority policies that must be implemented. 


\section{Jurnal Ekonomi Pembangunan, 17 (1), Juni 2016, 74-83}

In Table 1 three sectors contributed most the trade, hotels, restaurants, and the third one to Gross Domestic Product GDP in Central agricultural sector. Processing industry annually Java province is the first processing industry, contributes to GDP Central Java $>30 \%$.

Table 1 Contributions Sectors Against Gross Domestic Product GDP 2006-2010 (percent)

\begin{tabular}{lccccc}
\hline \multicolumn{1}{c}{ Sectors } & $\mathbf{2 0 0 6}$ & $\mathbf{2 0 0 7}$ & $\mathbf{2 0 0 8}$ & $\mathbf{2 0 0 9}$ & $\mathbf{2 0 1 0}$ \\
\hline Agriculture & 20,57 & 20,03 & 19,96 & 19,30 & 18,69 \\
Mining & 1,11 & 1,12 & 1,10 & 1,11 & 1,12 \\
Manufacturing Industries & 31,98 & 31,97 & 31,68 & 32,51 & 32,83 \\
Electricity, gas and water & 0,83 & 0,84 & 0,84 & 0,84 & 0,86 \\
Building & 5,61 & 5,69 & 5,75 & 5,83 & 5,89 \\
Trade, hotels and restaurants & 21,11 & 21,30 & 21,23 & 21,38 & 21,42 \\
Communication & 2,95 & 5,06 & 5,16 & 5,20 & 5,24 \\
Finance & 3,58 & 3,62 & 3,71 & 3,79 & 3,76 \\
Services & 10,25 & 10,36 & 10,57 & 10,03 & 10,18 \\
\hline
\end{tabular}

Source: BPS, Central Java in Figures 2007-2011

Trade, hotels and restaurants contributed an average of $21 \%$. In the agricultural sector contribution to always declined every year, in 2006 amounted to $20.57 \%$ to $18.68 \%$ in 2010. This was caused by the rapid growth of the industry which is now starting to shift the contribution of the agricultural sector. Central Java's economic growth rate during the period 2006 to 2010 have economic growth tends to increase. The rate of economic growth in Central Java can be seen from 2006 to 2008, in 2006 amounted to $5.33 \%$ increase to $5.59 \%$ in 2007 and continue to increase $5.61 \%$ in 2008 . However, in 2009 a decline the rate of economic growth to be $5.14 \%$. A decrease in the rate of economic growth in Central Java, did not last long because in 2010 has increased back to $5.84 \%$. Over the last five years, economic growth in Central Java province has increased and little fluctuation, but interesting Central Java province is not less than the other provinces in terms of infrastructure and in terms of natural resources. Central Java also has the advantage of geographical location because it is located between West Java and East Java, so there is a high population mobility in Central Java, if utilized properly will help the economic growth of Central Java.

Based on these two tables show that the sectors in Central and economic growth as the fluctuation. The growth rate decreased most sharply in 2009 which is down by $0.47 \%$ and increased again in 2010 rose by $0.70 \%$. The influence of these sectors on the rate of economic growth in Central Java is still not visible, but one of the drivers of economic growth is the increase in the export sectors of the economy both agriculture as the primary sector, the industrial sector and the processing as the secondary sector, the trade sector as the tertiary sector, See how big the influence of each of these sectors on the rate of economic growth in Central and searching for sectors of the base or seed every 15 City/Regency in Central Java (Surakarta, Semarang, Salatiga, Pekalongan, Wonogiri, Sukoharjo, Karanganyar, Sragen, Boyolali, Klaten, City/Country Semarang, Magelang, Kendal, Kebumen and Purworejo), so that the necessary analysis on a sector basis 


\section{Jurnal Ekonomi Pembangunan, 17 (1), Juni 2016, 74-83}

through Location Quotion and Panel Data to see the influence of the leading sectors in the rate of economic growth in Central Java in 2007-2011. (Daryono et al, 2013).

This study aims to identify a sector basis at 15 City/country in Central Java. and to analyze the effect of a sector basis in 15 City/country to economic growth in Central Java.

In the form of a formula, when used is data of each sector of the city/country in Central Java 2007-2011, it can be written as follows:

$$
L Q=\frac{1_{i} / e}{L_{i} / E}
$$

\section{Research Method}

In analyzing the economic growth more clearly needs to be determined first base sectors of the agricultural sector as the primary sector, the industrial sector and the processing as the secondary sector, the trade sector as the tertiary sector in the 15 City/County Central Java. Sector base serves as a reference if the City/County is self-sufficient or exporting goods and services to other regions. So it needs to be studied further how big a role the basic sector of the 15 City/ Country on economic growth in Central Java. Therefore, in this study, we propose a question: at 15 City-Regency/District in Central Java Which sectors have a base?

\section{Result and Discussion}

LQ analysis in a particular sector is done by comparing the share of the primary sector, secondary and tertiary through workforce - to the total at the level of city/county to share the same sector of the total at the provincial level (often called reference region, which is a larger area of regional/local analyzed or supra-regional). Where if the share value of the sector in the region is greater than the share of the sector at the national level, the excess portion can explain the value of exports (sent to other areas) happens.

Based on the calculation Location Quotient each city/county per year and per sector discussion of the study variables can be explained by statistical research data. Three variables in this study that sought his LQ value was agriculture as the primary sector, the industrial sector as the secondary sector and the trade sector as the tertiary sector in the year 2007-2011 in which the election of the three variables in these sectors based on the employment rate is highest among 9 other sectors.

Table2 Primary Sector LQ Value City/District in 2007-2011

\begin{tabular}{|c|c|c|c|c|c|}
\hline \multirow{2}{*}{$\begin{array}{c}\text { Cities/ } \\
\text { District }\end{array}$} & \multicolumn{5}{|c|}{ LQ Primary Sectors } \\
\hline & 2007 & 2008 & 2009 & 2010 & 2011 \\
\hline $\begin{array}{l}\text { Kota } \\
\text { Surakarta }\end{array}$ & 0,018 & 0,021 & 0,032 & 0,020 & 0,030 \\
\hline $\begin{array}{l}\text { Kota } \\
\text { Semarang }\end{array}$ & 0,097 & 0,118 & 0,093 & 0,059 & 0,116 \\
\hline $\begin{array}{l}\text { Kota } \\
\text { Salatiga }\end{array}$ & 0,191 & 0,283 & 0,273 & 0,124 & 0,257 \\
\hline $\begin{array}{l}\text { Kota } \\
\text { Pekalongan }\end{array}$ & 0,216 & 0,103 & 0,186 & 0,125 & 0,163 \\
\hline Wonogiri & 1,909 & 1,954 & 1,895 & 2,119 & 2,050 \\
\hline Sukoharjo & 0,662 & 0,639 & 0,775 & 0,640 & 0,452 \\
\hline Karanganyar & 0,881 & 0,936 & 0,893 & 0,940 & 1,053 \\
\hline Sragen & 1,319 & 1,207 & 1,347 & 1,347 & 1,451 \\
\hline Boyolali & 1,266 & 1,229 & 1,283 & 1,333 & 1,112 \\
\hline Klaten & 0,686 & 0,787 & 0,727 & 0,644 & 0,731 \\
\hline Semarang & 1,116 & 1,038 & 1,114 & 1,155 & 1,392 \\
\hline $\begin{array}{l}\text { Kota } \\
\text { Magelang }\end{array}$ & 0,048 & 0,048 & 0,078 & 0,031 & 0,035 \\
\hline Kendal & 1,526 & 1,575 & 1,509 & 1,585 & 1,577 \\
\hline Kebumen & 1,313 & 1,351 & 1,307 & 1,276 & 1,360 \\
\hline Purworejo & 1,401 & 1,441 & 1,342 & 1,415 & 1,318 \\
\hline
\end{tabular}

Source: LQ Data Processed 


\section{Jurnal Ekonomi Pembangunan, 17 (1), Juni 2016, 74-83}

Table 3 Value Smallest, Highest and Average Primary Sector LQ years 2007-2011

\begin{tabular}{lccccc}
\hline & $\mathbf{2 0 0 7}$ & $\mathbf{2 0 0 8}$ & $\mathbf{2 0 0 9}$ & $\mathbf{2 0 1 0}$ & $\mathbf{2 0 1 1}$ \\
\hline Min & 0,018 & 0,021 & 0,032 & 0,020 & 0,030 \\
Max & 1,909 & 1,954 & 1,895 & 2,119 & 2,050 \\
Average & 0,843 & 0,849 & 0,857 & 0,854 & 0,873 \\
\hline
\end{tabular}

Source:LQ Data of Data Processed in Excel

The low value of the primary sector LQ in Surakarta, Magelang and city/other districts in Central Java showed the primary sector or the agricultural sector is not a sector mainstay export base in the area. Table 4.6 of the average value (average) LQ primary sector in 20072011 amounted to (0.843) (0.849) (0.857) (0.854) and (0.873), suggesting a tendency areas in Central Java is not has an advantage in the primary sector, which means that the role of the agricultural sector excellence views of labor used to serve outside the territory smaller than the domestic sphere. In a self-sufficient area that has $\mathrm{LQ}>1$, such as the district of Wonogiri who does have climates cool and have a water source of its own, namely the reservoir, the district wonogiri able to export most of their agricultural products to other regions, as is sufficient to meet their own needs.

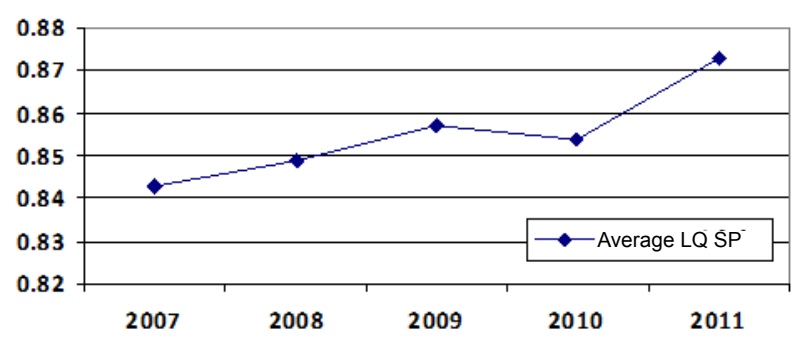

Graph 1. Dynamics of average LQ Primary Sector in 2007-2011

Source: Data Processed in excel

Illustrated in chart 1 the average fluctuations in the agricultural sector LQ 20072011. The agricultural sector in 15 cities/counties tend to rise in spite of having $\mathrm{LQ}<1$. The increase occurred in 2007-2009 but declined again in 2010. The decrease is caused by the seasonal cycle is erratic. The increase in re-occur quite high in 2011 at 0.0019 . From the graph one can conclude that the trend of rising agricultural sector is not matched by the use of natural and human resources sufficient and efficient to meet the needs of the area at 15 is still lacking and can not be exported outside the region.

Table 4. Secondary Sector LQ Value City/District in 2007-2011

\begin{tabular}{lccccc}
\hline \multirow{2}{*}{$\begin{array}{c}\text { Countries/ } \\
\text { District }\end{array}$} & \multicolumn{5}{c}{ LQ Secondary Sector } \\
\cline { 2 - 6 } $\begin{array}{l}\text { Kota } \\
\text { Surakarta }\end{array}$ & $\mathbf{2 0 0 7}$ & $\mathbf{2 0 0 8}$ & $\mathbf{2 0 0 9}$ & $\mathbf{2 0 1 0}$ & $\mathbf{2 0 1 1}$ \\
Kota & 1,009 & 1,014 & 1,037 & 0,970 \\
Semarang & 1,138 & 1,066 & 1,077 & 1,144 & 0,958 \\
Kota Salatiga & 1,181 & 1,050 & 0,935 & 0,895 & 1,192 \\
Kota & 2,024 & 2,127 & 2,197 & 2,084 & 1,625 \\
Pekalongan & & & & & \\
Wonogiri & 0,271 & 0,307 & 0,301 & 0,352 & 0,491 \\
Sukoharjo & 1,402 & 1,447 & 1,346 & 1,433 & 1,437 \\
Karanganyar & 1,089 & 0,997 & 0,925 & 0,966 & 1,054 \\
Sragen & 0,653 & 0,867 & 0,785 & 0,752 & 0,647 \\
Boyolali & 0,889 & 0,858 & 0,842 & 0,824 & 0,926 \\
Klaten & 1,232 & 1,165 & 1,298 & 1,235 & 1,390 \\
Semarang & 1,258 & 1,362 & 1,290 & 1,350 & 1,031 \\
Kota & 0,736 & 0,712 & 0,640 & 0,794 & 0,586 \\
Magelang & 0,686 & 0,731 & 0,726 & 0,631 & 0,741 \\
Kendal & 1,212 & 1,196 & 1,255 & 1,167 & 1,489 \\
Kebumen & 0,721 & 0,690 & 0,842 & 0,695 & 0,440 \\
\hline Purworejo & & & &
\end{tabular}

Source: LQ of Data Processed

LQ secondary sector provides an overview of regional advantage in building the secondary sector (industry and processing) as a regional export base. In Table 4 shows the 2007 to 2011 the city of Pekalongan has the highest LQ value although in 2011 decreased where its value is equal to LQ (2.024) (2.127) (2.197) (2.084) and (1.625). Wonogiri into areas that have the lowest value of LQ in 2007 to 2010 in the amount of (0.271) (0.307) (0.301) and (0.352). In 2011 the district Purworejo be an area that has a value that is equal to the next lowest LQ (0.440). Of the study sample as many as 15 local cities/ 


\section{Jurnal Ekonomi Pembangunan, 17 (1), Juni 2016, 74-83}

regencies in Central Java, which has a value of LQ> 1 in 2007 as many as 9 regions, while in 2008 there were 8 regions, 2009-2011 for 7 regions. Area LQ> 1 means it has the advantage in the secondary or industrial sector. Meanwhile, the city/county that has a value LQ $<1$ in 2007 by 6 regions, in 2008 as many as seven regions, 20092011 for 7 regions. Areas that have LQ $<1$ mean not have the advantage in the secondary sector.

Table 5. Value Smallest, Highest and Average Secondary Sector LQ years 2007-2011

\begin{tabular}{lccccc}
\hline & 2007 & 2008 & 2009 & 2010 & 2011 \\
\hline Min & 0,271 & 0,307 & 0,301 & 0,352 & 0,440 \\
Max & 2,024 & 2,127 & 2,197 & 2,084 & 1,625 \\
Average & 1,052 & 1,039 & 1,032 & 1,024 & 0,998 \\
\hline
\end{tabular}

Source: LQ of Data Processed in Excel

The low value of the secondary sector LQ in Wonogiri district, Purworejo counties and cities/regencies in Central Java demonstrate the secondary sector or the industrial sector instead of being the leading sectors export base in the area. From table 5 the average value (average) LQ secondary sector in 2007-2011 amounted to (1.052) (1.039) (1.032) (1.024) and (0.998), suggesting a tendency areas in Central Java have excellence in the secondary sector, which means that the role of the industrial sector views of labor used to serve outside the territory is greater than the domestic sphere. In a self-sufficient area that has $\mathrm{LQ}>1$, such as Pekalongan district that does have focused on the area of industry as an example is the famous Pekalongan batik to be able to export the majority of industrial products to other regions.

Illustrated on the graph 2 , the average fluctuation LQ industrial sector in 2007-2011. The industrial sector in 15 cities/counties tend to decrease in the years 2007-2010, in which the most drastic decline in 2011 amounted to 0,026 . The decline occurred as a result of the influence of seasonal factors, competitive product similar and deteriorating market situation. From chart 2 we can conclude that the trend decline in the industrial sector is not matched by the use of human resources efficiently in producing so fulfilling the needs in the domestic area is still lacking. Therefore, began to use the technology to replace human resources as a factor of production has led to the decrease in absorption of labor in 2007-2011.

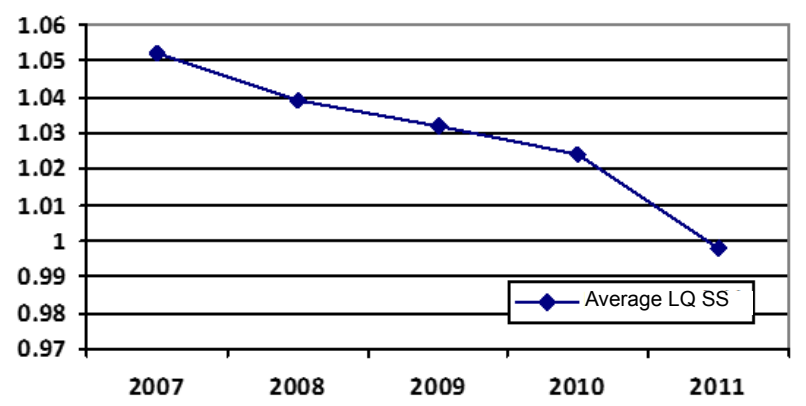

Graph 2 Dynamics of average LQ Secondary Sector 2007-2011 year

Source: Graph 2. LQ of Data Processed in Excelindustrial sectors

Table 6. LQ Value Tertiary Sector in City/ District 2007-2011

\begin{tabular}{lccccc}
\hline \multicolumn{1}{c}{ Cities/ } & \multicolumn{5}{c}{ LQ Tertiery Sector } \\
\cline { 2 - 6 } District & $\mathbf{2 0 0 7}$ & $\mathbf{2 0 0 8}$ & $\mathbf{2 0 0 9}$ & $\mathbf{2 0 1 0}$ & $\mathbf{2 0 1 1}$ \\
\hline Surakarta & 1,897 & 1,887 & 1,803 & 1,774 & 1,505 \\
City & & & & & \\
Semarang & 1,336 & 1,478 & 1,404 & 1,424 & 1,511 \\
City & & & & & \\
Salatiga City & 1,236 & 1,212 & 1,091 & 1,265 & 1,317 \\
Pekalongan & 1,305 & 1,293 & 1,158 & 1,180 & 1,242 \\
City & 0,600 & 0,580 & 0,634 & 0,511 & 0,592 \\
Wonogiri & 1,089 & 1,119 & 1,030 & 1,068 & 1,189 \\
Sukoharjo & 1,025 & 0,999 & 0,992 & 0,969 & 0,829 \\
Karanganyar & & & & & \\
Sragen & 0,987 & 0,961 & 0,963 & 0,963 & 1,016 \\
Boyolali & 0,824 & 0,905 & 0,913 & 0,875 & 0,810 \\
Klaten & 1,197 & 1,150 & 1,230 & 1,208 & 1,033 \\
Semarang & 0,713 & 0,807 & 0,754 & 0,758 & 0,747 \\
Magelang & 1,991 & 1,717 & 1,623 & 1,572 & 1,788 \\
City & 0,880 & 0,724 & 0,757 & 0,755 & 0,860 \\
Kendal & 0,691 & 0,640 & 0,774 & 0,802 & 0,595 \\
Kebumen & 0,900 & 0,831 & 0,813 & 0,906 & 1,099 \\
Purworejo & & & & & \\
\hline
\end{tabular}




\section{Jurnal Ekonomi Pembangunan, 17 (1), Juni 2016, 74-83}

LQ tertiary sector provides an overview of regional advantage in building the tertiary sector (trade) as a regional export base. In Table 6 shows the 2007-2011 Magelang has the highest LQ value of (1.991) and (1.788). While in 2008, 2009 and 2010 the city of Surakarta has the next highest LQ LQ where its value is equal to (1.887) (1.804) and (1.774). In the years 2007-2011 Wonogiri district into areas that have a value that is equal to the lowest LQ (0.445) (0.580) (0.634) (0.511) and (0.592).

Of the study sample as many as 15 local cities/regencies in Central Java, an area that has a value of $L Q>1$ in 2007 as many as eight local city/county, while in 2008-2010 there were seven areas, the year 2011 as many as nine areas. Area LQ> 1 means it has the advantage in the tertiary sector. Meanwhile, the city/county that has a value $L Q<1$ in 2007 by 7 regions, 2008-2009 by 8 regions, and in 2011 as many as 6 areas that have $\mathrm{LQ}<1$. Areas that have $\mathrm{LQ}<1$ berrati not have the advantage in the tertiary sector.

Table 7. Value LQ Smallest, Highest and Average Tertiary Sector, years 2007-2011

\begin{tabular}{llllll}
\hline & $\mathbf{2 0 0 7}$ & $\mathbf{2 0 0 8}$ & $\mathbf{2 0 0 9}$ & $\mathbf{2 0 1 0}$ & $\mathbf{2 0 1 1}$ \\
\hline Min & 0,600 & 0,580 & 0,634 & 0,511 & 0,592 \\
Max & 1,991 & 1,887 & 1,803 & 1,774 & 1,788 \\
Average & 1,111 & 1,087 & 1,063 & 1,069 & 1,076 \\
\hline
\end{tabular}

Source: LQ of Data Processed in Excel

The low value of the tertiary sector LQ in Wonogiriregency and city/other districtsin Central Java showed the tertiary sector or commercial sector is not a sector mainstay export base in the area. From table 7 average value (average) LQ tertiary sector in 2007-2011 amounted to $(1,111)$ $(1,087)(1,0,63),(1.069)$ and (1.076), suggesting a tendency areas in Central Java has the advantage in the tertiary sector, which means that the role of the trade sector views of labor used to serve outside the territory is greater than the domestic sphere. In a self-sufficient area that has $L Q>1$, such as the district of Surakarta who does have the traditional markets and modern markets are pretty much and merchants do not require special skills to sell, so that the number of workers absorbed in trade and are able to export most of the results wares to other regions.

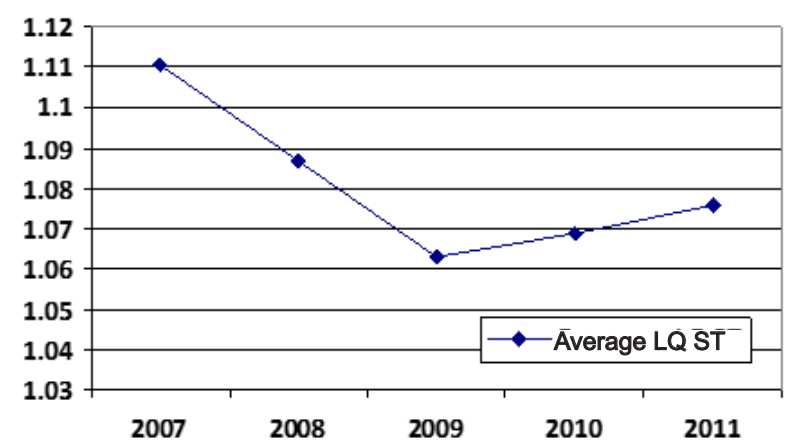

Graph 3. Dynamics of Tertiary Sector Average year 2007-2011

Source: LQ of data processed in Excel

Illustrated on the graph 3 , the average fluctuation LQ trade sector 2007-2011. The trade sector in 15 cities/counties tended to decline in 2007-2009, and climbed back in 2009-2011 where the increase is not proportional to the decline that occurred in the previous year. Fluctuations in the trading sector impact on labor productivity of the sector in order to meet the demand of its territory, despite a sharp decline in 2009-2011, but the average value of $L Q$ trade sector is still greater than 1 . From chart 3 we can conclude that the upward trend the decline in the trade sector due to raw material prices are constantly changing, transitional livelihoods traders and seasonal factors are uncertain.

Central Java Province covers an area of $32548.20 \mathrm{~km}$ or about 25.04 percent of the island of Java (1.70 percent of Indonesia). Central Java Province is a region with diverse topography, which is a plains, plateaus, mountains and coastal areas. Approximately 53.30 percent of the province of Central Java at an altitude between 0 to 100 meters above sea level. The climate in Central Java, including dry and wet with rainfall varied, either dry or wet areas range from 800 


\section{Jurnal Ekonomi Pembangunan, 17 (1), Juni 2016, 74-83}

to 8,890 millimeters annually. Administratively in Central Java, there are 35 districts/cities, composed of 29 districts and 6 cities.

Central Java became one of the provinces with natural resources and human resources are abundant. The use of natural resources and the human resources are sometimes still not up, so that the results obtained were also not maximized. The local government as the holder of an important role in making policy to create an area has high productivity, which with the productivity of economic growth can be maintained. By looking at sectors of the economy as a yardstick of economic growth, the sector is the largest potential as konstributor with the maximum efficiency and utilization of natural resources and human resources. Based on the research that has been conducted in 15 cities/counties in 2007-2011 using panel data the primary sector (agriculture), secondary (industry) and trade (tertiary) has significant influence on the economic growth in Central Java with a $99 \%$ confidence level. The primary sector has a negative impact on the economic growth of -9.491. Secondary sector has a positive impact on economic growth amounted to 15.630. The tertiary sector has a positive impact on economic growth amounted to 24.786.

The cause of the negative impacts of agricultural sector is the average of the agricultural sector basis is less than 1, according to the results of the analysis of LQ that 15 cities/ regencies in Central Java does not have the advantage in the agricultural sector. The results support previous research conducted by Agustono (2013) where the agricultural sector's contribution to economic growth fluctuated even negative. In contrast to the industrial and trade sectors in which its contribution fluctuated but none showed a negative contribution to economic growth. There are some areas that have excelled in the primary sector (agriculture) is Wonogiri, Sragen, Boyolali, Semarang, Kendal, Kebumen, and Purworejo have bases in the agriculture sector. Although there are some areas which have become a sector basis, but the average of the primary sector in the 15 city/county is still below the number 1. Excellence has become a base area than the city/other districts should be best utilized by the Government as a reference fixing region non-basis or who does not have the advantage in the agricultural sector. One way is to transfer the vacant land into agricultural land as an example of improvement efforts in the agricultural sector.

The importance of the role of agriculture in the economy should state policies such as fiscal policy, monetary policy, and trade policy does not ignore the potential of the agricultural sector. One of the main challenges in moving performance and utilize the agricultural sector is the use of human resources and technology that is balanced as well as capital or investments in the sector. Development of investment in the agricultural sector needed to spur economic growth, increase employment opportunities and incomes of farmers, as well as regional development, especially rural areas.

The agricultural sector have a negative impact on economic growth because when the agricultural sector rise, economic growth will fall. Although employment in the agricultural sector absorbed a lot but could reduce economic growth. This can be caused by factors location, season, natural disasters such as floods and volcanoes erupt, pests and diseases associated with the government's policy of fiscal and monetary. Problems in the agricultural sector in increasing food production to be one of the main problems. This is because of the limited land that could be used for farming. The development of increasingly large population makes the need for residential land and various means of supporting community life also increased. Industrial development also makes technical irrigated agriculture wane.

Another cause of the negative impact of the agricultural sector to economic growth is due to supply water to irrigate agricultural land is also reduced. Many reservoirs, irrigation canals that there needs to be repaired, tropical forests there are diminishing returns, coupled with the El Nino weather cycle-La Nina because of the 


\section{Jurnal Ekonomi Pembangunan, 17 (1), Juni 2016, 74-83}

influence of global warming further reducing the supply of water that flowed from the mountains to farmland. Import rice from abroad is the focus of why the agriculture sector in Indonesia, especially in Central Java can not be independent. The government should be entrusted fully to the agricultural sector of society who works in the sector by providing adequate facilities for farming and cultivation.

Secondary sector had a positive impact on economic growth. This is consistent with the theory and call for support previous research conducted by Fauzi Hussin and Wuan Chee Ching (2013), when the industrial sector increases, economic growth has also increased. Secondary sector has an average value of more than 1 base sector where the advantages of the region also have a positive impact on economic growth.

The average secondary sector declined in 2011 possibility is the use of human resources in the industrial sector in 15 cities /counties in the industrial sector which develops mostly large and medium industries that rely more mechanization and experts where workers more than experts, so that laborers do not get the jobs they deserve. Factors excellence areas that have the basic sector as Surakarta, Semarang, Salatiga, Pekalongan, Sukoharjo, Karanganyar, Klaten, Semarang and Kebumen become an important factor rising economic growth in Central Java. Although the sector average base of more than 1 , there are still areas that do not have the advantage in the industrial sector that needs the attention of the government to increase productivity and able to provide konstribusinya and utilized by other regions. In addition, the government needs to maintain a city/county that has become the basis for the sector has to contribute substantially to the economic growth in Central Java.

The tertiary sector had a positive impact on economic growth. This is consistent with the initial hypothesis which affects the tertiary sector exhibited significantly to economic growth, if trade increases, economic growth has also increased. Tertiery sector has an average value of more than 1 base sector where the advantages of the region also have a positive impact on economic growth. Regions that have superior sector is the city of Surakarta, Semarang, Salatiga, Pekalongan, Magelang, Sukoharjo, Karanganyar, Klaten, Sragen and Purworejo.

Trade became one of the promising prospects for the community if you want to work in the sector. People do not need to trade higher education, enough capital and know how to trade and earn revenue or profits. The number of traditional and modern markets in Central Java became one of the places for traders to trade large and small. Problem arising in the trade sector usually is a matter of raw materials that are hard to find so inevitably the seller will raise prices, causing inflation, when inflation occurs, the purchasing power will decline and the seller will lose money. This is the loss incurred in the event of inflation, therefore the attitude of the government in empowering local communities has been focused on the trade sector is providing the perfect place for traders and keep the raw materials remains the sector that contribute greatly to the economic growth is maintained.

\section{Conclusions}

Based on the results of the analysis have been discussed in the previous chapter, then in this experiment can be summarized as follows:

The sectors that have high labor absorption in Central Java role as a key sector in the economic growth. Components that contribute to the growth were agriculture, industry and trade.

There are eight areas that have the advantage of primary sector Wonogiri, Sragen, Boyolali, Semarang, Kendal, Kebumen, and Purworejo. Areas that have the advantage of the secondary sector there are nine regions, namely Kota Surakarta, Semarang, Salatiga, Pekalongan, Sukoharjo, Karanganyar, Klaten, Semarang and Kebumen. While the areas that have the advantage of the tertiary sector there 
are 10 areas of the city of Surakarta, Semarang, Salatiga, Pekalongan, Magelang, Sukoharjo, Karanganyar, Klaten, Sragen and Purworejo.

\section{Suggestion}

Based on an analysis of the determinants of the basic sector to economic growth in Central Java, the suggestions can be submitted are:

Central Java provincial government is expected to pay attention to and improve infrastructure or supporting factors that influence the development of nonbasisnya sector, so as to increase and make non-basis sector as a sector which is the basis of the leading sectors in the province of Central Java. For example, with an increase in the mastery of technology in all the sectors, simplify the requirements in capital investment, improve communication and information networks in the industry, complete infrastructure, vacant land into agricultural land as an example of improvement efforts in the agricultural sector.

\section{Reference}

Agustono, 2013. Analisis Sektor Pertanian Ditinjau dari Peran Terhadap Pertumbuhan dan Stabilitas Produk Domestik Regional Bruto Di Provinsi Jawa Tengah. Jurnal SEPA: Vol. 9 No. 2 Februari 2013 : 283 - 296.

Amstrong Harvey \& Jim Taylor 2010, Regional Economics \& Policy, Fifth Edition, Harvester Weatsheaf Campus, mayland Avenue, Great Britain

Arikunto, Suharsimi. 2006. Prosedur Penelitian Suatu Pendekatan Praktik. Jakarta: Rineka Cipta.

Aziz, Abdul dkk. 2012. Analisis Sektor Unggulan dan Perkembangan Ekonomi Kabupaten Lamongan. Jurnal: JESP Vol. 4, No.2, 2012

2010. Ekonomi Pembangunan. Yogyakarta: UPP STIM YKPN.

Badan Pusat Statistik: Jawa Tengah dalam Angka 2008. Semarang: Badan Pusat Statistik Jawa Tengah.
:Jawa Tengah dalam Angka 2009. Semarang: Badan Pusat Statistik Jawa Tengah.

:Jawa Tengah dalam Angka 2010. Semarang: Badan Pusat Statistik Jawa Tengah.

:Jawa Tengah dalam Angka 2011. Semarang: Badan Pusat Statistik Jawa Tengah.

:Jawa Tengah dalam Angka 2012. Semarang: Badan Pusat Statistik Jawa Tengah.

Badan Pusat Statistik Indonesia. Website BPS: http://www.bps.go.id/tab_sub/ view .ph p ? tabel $=1 \&$ daftar $=1 \&$ id subyek $=52 \&$ notab $=3$. diakses tanggal 16 Januari 2014.

Badrudin, Rudi. 2012. Ekonomika Otonomi Daerah. Yogyakarta: UPP STIM YKPN.

Basuki, Agus Tri dan Utari Gayatri, 2009 Penentu

Sektor Unggulan dalam Pembangunan Daerah: Studi Kasus di Kabupaten Ogan Komering Ilir. Jurnal Ekonomi dan Studi Pembangunan: Vol.10 April 2009 : $34-50$.

Bendavid-Val, Avrom. 1991. Regional and Local Economic Analysis for Practiticioners, $4^{\text {th }}$ edition, Praeger, New York, 1991.

Boedijoewono, Noegroho. 2007. Pengantar Statistika. Yogyakarta: UPP STIM YKPN.

Boediono, 1999, Teori Pertumbuhan Ekonomi. Yogyakarta: BPFE.

Boschma, R.A. 2004. Competitiveness of regions from an evolutionary perspective, Regional Studies. 38: $993-1006$.

Daryono Soebagiyo, 2013, Regional Competitiveness and Its Implications For Development, JEP Vol 14, No.2, Desember 2013 Balai Penelitian dan Pengembangan Ekonomi, UMS, Surakarta.

Daryono Soebagiyo, 2008, Analisis Kompetensi Unggulan daerah Pada Produk batik Tulis dan Cap di Dati II Kota Surakarta, JEP Vol.9, No.2 Desember 2008 


\section{Jurnal Ekonomi Pembangunan, 17 (1), Juni 2016, 74-83}

Daryono Soebagiyo dan Darmansyah, 2010 Stimulus Ekspor Terhadap Kinerja Perusahaan Perusahaan batik, JEP Vol 11 No.2 Desember 2011

Daryono Soebagiyo, Triyono, Yuli Tri Cahyono, 2013, Analisis Daya Saing Daerah dan Implikasinya terhadap Pembangunan Wilayah di Jawa Tengah (Penelitian PUPTDikti Tahap 1 2013).

Daryono Soebagiyo, Triyono, Yuli Tri Cahyono, 2014, Analisis Daya Saing Daerah dan Implikasinya terhadap Pembangunan Wilayah di Jawa Tengah (Penelitian PUPTDikti Tahap 2 2014) Daryono Soebagiyo, Triyono, Yuli Tri Cahyono

Djakapermana, R.D. 2010. Pengembangan Wilayah Melalui Pendekatan Kesisteman. Bogor: IPB Press.

Firman, Achmad. 2007. Analisis dampak Investasi Sektor Peternakan Terhadap Perekonomian di Jawa Tengah. http://www.Pustaka. Unpad.ac.id. diakses tanggal 9 Juni 2014.

Glasson, John. 1978. An Introduction to Regional Planning. London.

Gujarati, Damodar N. 2003. Basic Econometrics. New York: McGraw-Hill/Irwin Companies, Inc.

Hasan, I. 2004.Analisis Dana Penelitian Dengan Statistik. Jakarta: Bumi Aksara.

Hussin and Wuan Ching. 2013. The Contribution of Economic Sectors to Economic Growth: The Cases of Malaysia and China. International Journal of Academic Research in Economics and Management Sciences. Vol.2 No.2 Maret 2013.

Jhingan, M.L. 1999. Ekonomi Pembangunan dan Perencanaan. Jakarta: PT Raja Grafindo Persada.

2007. Ekonomi Pembangunan dan Perencanaan. Jakarta: PT Raja Grafindo Persada.

Juanda, Bambang. 2012. Ekonometrika Deret Waktu Teori dan Aplikasi. Bogor: PT Penerbit IPB Presss.
Richardson Harry W, 2010, Regional Economics, University of Illinois Press, United States of America

Richardson Harry W, 2009, The Regional Framework: The Measurement on Regions, Regional Economics

Soleh, Achmad. 2012. Konstribusi dan Daya Saing Ekspor Sektor Unggulan dalam Perekonomian Jawa Tengah. Fakultas Ekonomika dan Bisnis, Universitas Diponegoro. Semarang.

Stevenson,W.J. 1999. Production/Operations Management (6th.ed.), BurrRidge,IL: Irwin/ McGraw-Hill.

Tarigan, Robinson. 2005. Ekonomi Regional Teori dan Aplikasi. Jakarta : PT.Bumi Aksara.

2012. Ekonomi Regional Teori dan Aplikasi (edisi revisi). Jakarta : PT.Bumi Aksara.

Todaro, Michael P. 2003. Pembangunan Ekonomi di Dunia Ketiga. Alih Bahasa: Aminuddin dan Mursid. Jakarta: Ghalia Indonesia.

Tjokroamodjojo, Bintoro. 1993. Perencanaan Pembangunan. Jakarta: CV. Haji Masagung.

Trenggonowati, Dr. 2009. Metodologi Penelitian Ekonomi dan Bisnis edisi pertama. BPFE: Yogyakarta.

Widodo, Tri. 2006. Perencanaan Pembangunan : Aplikasi Komputer. Yogyakarta: UPP STIM YKPN.

Wikipedia. http://id.wikipedia.org/wiki/Sektor ekonomi_tersier. diakses tanggal 10 Juni 2014.

Winarno, Wing Wahyu. 2009. Analisis Ekonometrika dan Statistika dengan Eviews. Yogyakarta: Sekolah Tinggi Ilmu Manajemen YKPN.

Wise and Shtylla. 2007. The Role of the Extractive Sector in Expanding Economic Opportunity. Harvard University. 